\title{
Geographical Analysis of General Land Use Change in Latur and Nilanga Tahsil(1993-96 to 2010-13)
}

\author{
O.M. Jadhav \\ Assistant Professor \\ Shivneri Mahavidyalaya, \\ Shirur Anatpal,MH, India.
}

\begin{abstract}
Men fulfill their basic need from land. They have being used land for cultivation and settlement. Hence, the relationship of people with land is as old as man. The analysis of land use change is essentially to the analysis of changing relationship between people and land. Dynamic movement of people can be detected through this study. Day by day population pressure is increased on land. Hence proper use of land is very important for sustainable development of any region. Every change in land use should be noticed for development planning and management. In this study Technical Committee on Co-ordination of Agricultural Statistics (T.C.C.A.S.) recommendations of standard classification of land class has been considered. Latur and Nilanga Tahsil of Marathwada region are chosen as study area. The regional variations in spatial pattern of land uses are examined from 1993-96 to 2010-2013. Categorywise more change has been observed in land put to non agricultural use and net sown area. Negative change has observed in land put to non agricultural use, barren lands, permanent pastures and other grazing land, area under miscellaneous tree crops etc., cultural waste land, current fallows and other fallow land. Positive change has observed net sown and area under forest. It is good sign for study region development.
\end{abstract}

Keywords: Lund Use Study, Land Use Change Study

\section{INTRODUCTION}

Land use study is the base of any regional planning. Use of land defines relationship between human activity and land. Land use is not new in geography. Land use means the surface utilization of all developed and vacant land on a specific point at a given time and space. This change may be due to two most probable reasons. Firstly, the requirements of the society may be the cause for bringing change in the land use. Secondly, the technological impact also promotes changes so that an individual as well as the society is able to maximize the advantages. The demand for new uses of land may be stimulated by a technological change or by a change in size, compositions and requirements of a concerning community. Some changes are short lived while others represent a more constant demand (J.N. Jakson 1963). The study of land use is of pivotal importance in the point of view of planning and development of an area. "It is natural that different types of living which are represented by social values and certain industrial controls will create different patterns of land use within the limits imposed by different agro-physical controls" (Jasbir Singh, 1974)

\section{STUDY AREA}

Study region is part of Latur district. Latur district is included ten tahsils. This study area consist current Latur tahsil and area of Nilanga tahsil before 23 June 1999. These are important tahsils of Latur district. Latur tahsil is divided into following five revenue circles. These are Kasarkheda, Latur, Gategaon, Tandulja and Murud. Nilanga tahsil is divided into following eight revenue circles. These are Nilanga, Shirur Anantpal, Hisamabad, Ambulga, Kssarshirshi, Kasar Balkunda, Madansuri and Aurad Shahajani. Latur tahsil is located in the north western part of Latur district. Nilanga tahsil is located in the southern part of latur district. Study area North side is bounded by Renapur and Chakur tahsil. East side is bounded by Udgir and Deoni tahsil. South and West side is bounded by Ausa tahsil and Osmanabad district. Study area lies between $17^{0} 52^{\prime}$ north to $18^{0} 32^{\prime}$ north latitudes and $76^{0} 12^{\prime}$ east to $76^{0} 41^{\prime}$ east longitudes. The total area of study is $2577.35 \mathrm{sq}$. $\mathrm{km}$.
The height of study region is in-between 510 to 700 meters from sea level. The main river is the Manjra flowing in the northern and eastern part of study area. Other important rivers are the Terna and Tawarja. Both rivers flow west to east direction through the study region. Study region is covered by deep black soil and medium black soil. The average normal rainfall of study region is 714 millimeters. There is lot of variation in temporal and spatial distribution of rainfall in study area.

\section{OBJECTIVES}

1) To examine the general land use pattern under nine categories of land use.

2) To identify change in general land use pattern from 1993 to 2013.

\section{METHODOLOGIES}

In India as per the Technical Committee on Coordination of Agricultural Statistics (T.C.C.A.S.) recommendations of standard classification, the total geographical area of study area is divided into nine land use categories. The following are the main land use categories. 1) Area under forest 2) Areas under non agricultural uses 3) Barren lands 4) Permanent pastures and other grazing land 5) Area under miscellaneous tree crops etc 6) Cultural waste land 7) Current fallows 8) Other fallow land 9) Net sown area. Area under all land use categories has been collected circlewise form Socio- economic review and district statistical abstract of Latur district, District census \& hand book, Gazetteer, Agricultural epitomes, season and crops reports published by the department of agriculture. Volume of Change is calculated using in following formula.

Volume of Change $=($ Last Year Land use Area in \% $)-($ Base Year Land use Area in \%)

\section{RESULT AND DISCUSSIONS:}

5.1 Circlewise changes in general land use from 19931996 to 2010-13: There are differences in physical factors in different circles of study region. The general land use is shown by Map No. 1 and 2 . Table No. 1 indicates that the general land use of different circles of this region from 1993-1996 to 2010-13. 


\subsubsection{Transformations in Area under forest:}

The area under forest was 921 hectares in 1993-96 and it was 1702 hectares in 2010-13 in study region. The area under forest was increased by $0.30 \%$ in study region. Positive changes were recorded in Latur $(0.26 \%)$, Kasarkheda $(0.30 \%)$, Tandulja (0.19), Nilanga (0.11), Ambulga (0.20), Kasarshirsi (0.57), Kasarbalkunda (0.14), Madansuri (0.10) circles and nigativ changes were recorded in Aurad shajani 1.72) Murud (0.13), Gategoan (0.48). The highest positive change has been observed in Kasarshirsi circle $(0.57 \%)$ and the lowest positive change was recorded in Aurad shajani (1.72) circle during the period of 1993-96 to 2010-13.

\subsubsection{Transformations in Land Put to Non} Agricultural Uses: In this land use category negative transformations have been observed Latur (0.25\%), Kasarkheda $(0.52 \%)$, Murud $(0.13 \%)$, Gategon $(1.7 \%)$, Tandulja (1.55\%), Nilanga (0.98\%), Shirur Anatpal (0.63\%), Hismabad (0.82\%), Ambulga (3.15\%), Kasarshirsi (1.29\%), Kasarbalkunda (6.39\%), Madansuri (3.57\%) and Aurad shajani $(1.77 \%)$ circles during the period of $1993-96$ to $2010-13$. The highest nigative change was recorded in Kasarbalkunda $(6.39 \%)$ circle. Very significant change is observed in this category in study area. The area under non agricultural uses was $4.95 \%$ in $1993-96$ and it was $2.95 \%$ in $2010-13$. Overall $2 \%$ negative change has found in this category.

\subsubsection{Transformation in Barren and Uncultivable} Land:

The overall $1.19 \%$ negative change of this category is recorded during the period under study time. In this land use category negative transformations have been observed Latur $(0.18 \%)$, Kasarkheda $(0.73 \%)$, Murud (1.04\%), Gategon $(0.3 \%)$, Tandulja (1.0\%), Nilanga (1.65 \%), Shirur Anatpal (0.2\%), Hismabad (1.32\%), Ambulga (2.07\%), Kasarshirsi (1.34\%), Kasarbalkunda (4.36\%), Madansuri (1.41\%) and Aurad shajani $(0.6 \%)$ circles during the period of 1993-96 to 2010-13. The highest negative change in Barren and uncultivable land was recorded in kasarkheda (4.36\%) circle and the lowest negative change was noticed in Latur $(0.18 \%)$ circle during the period under study.

\subsubsection{Transformation in Cultivable Waste Land:}

The negative change has been recorded in area under cultivable waste land during the period under study. The highest negative change in under cultivable waste land was recorded in Kasarbalkunda $(3.3 \%)$ circle and the lowest negative change was noticed in Shirur Anatpal $(0.38 \%)$ circle during the period under study. The $1.16 \%$ negative change has been noticed in study region during the period 1993-96 to 201013. The negative change in cultivable waste land was observed in Latur $(0.57 \%)$, Kasarkheda $(0.89 \%)$, Murud $(1.1 \%)$, Gategon $(0.85 \%)$, Tandulja $(1.41 \%)$, Nilanga $(1.08 \%)$, Shirur Anatpal (0.38\%), Hismabad (2.19\%), Ambulga (1.06\%), Kasarshirsi (1.52\%), Kasarbalkunda (3.3\%), Madansuri $(0.83 \%)$ and Aurad shajani (1.07 \%) circles.

\subsubsection{Transformation in Permanent Pastures and Other Grazing Land:}

Negative changes have been observed in the area of this category. Nearly $1.12 \%$ was decreased in study area during the period 1993-96 to 2010-13. The highest negative change in area under permanent pastures and other grazing land was recorded in Kasarbalkunda (1.93\%) circle and the lowest negative change area under permanent pastures and other grazing land was observed in Latur $(0.23 \%)$ circle during the period under study. The negative change in permanent pastures and other grazing land was observed in Latur $(0.23 \%)$, Kasarkheda (0.49\%), Murud $(0.38 \%)$, Gategon $(0.69 \%)$, Tandulja (1.89\%), Nilanga (1.37\%), Shirur Anatpal
(1.25\%), Hismabad (1.42\%), Ambulga (0.66\%), Kasarshirsi $(0.95 \%)$, Kasarbalkunda (1.93\%), Madansuri $(1.47 \%)$ and Aurad shajani $(0.34 \%)$ circles.

5.1.6 Transformation in Land Under Miscellaneous Tree Crops and Groves Not Included in Net Sown Area: Area under this category negative change was observed in all the circles of study area during the period 1993-96 to 2010-13. The area under this category was decreased by 0.86 $\%$ during the period 1993-96 to 2010-13.

The highest negative change was recorded in Tandulja (1.9\%) circle and the lowest negative change was observed in Latur and Madansuri $(0.23 \%)$ circle during the period 1993-96 to 2010-13. The negative change in this category in Latur $(0.23 \%)$, Kasarkheda $(0.76 \%)$, Murud $(0.93 \%)$, Gategon $(0.26 \%)$, Tandulja (1.9\%), Nilanga (1.61\%), Shirur Anatpal (0.75\%), Hismabad (1.02\%), permanent pastures and other grazing land was observed in

Latur (0.23\%), Kasarkheda (0.49\%), Murud (0.38\%), Gategon $(0.69 \%)$, Tandulja (1.89\%), Nilanga (1.37\%), Shirur Anatpal $(1.25 \%)$, Hismabad (1.42\%), Ambulga (0.66\%), Kasarshirsi $(0.95 \%)$, Kasarbalkunda (1.93\%), Madansuri (1.47\%) and Aurad shajani $(0.34 \%)$ circles.

\subsubsection{Transformations in Current Fallows:}

Due to uneven monsoon rainfall, small size of holding, low per hectare yield of agriculture, the marginal land holding farmers put their land as a current fallow land. The average study area negative transformation of this category land is $0.72 \%$. The highest negative change in current fallows are observed in Shirur Anatpal (1.68\%) circle and the lowest negative transformations took place in Gategon $(0.09 \%)$ circle during the

The negative change in this category in Latur $(0.11 \%)$, Kasarkheda $(0.73 \%)$, Murud $(0.74 \%)$, Gategon $(0.09 \%)$, Tandulja (1.37\%), Nilanga (-0.57\%), Shirur Anatpal (1.68\%), Hismabad (0.72\%), Ambulga (0.88\%), Kasarshirsi (0.9\%), Kasarbalkunda (0.95\%), Madansuri (0.68\%) and Aurad shajani $(0.2 \%)$ circles. Due to population pressure increased in study area the area under current fallows has been decreased.

\subsubsection{Transformations in Other Fallows:}

Nearly $0.68 \%$ area under other fallow land is also decreased in Latur and Nilanga tahsil. The highest negative change in area under other fallows has been recorded in Kasarbalkunda $(0.93 \%)$ circle and the lowest negative change was observed in Latur $(0.17 \%)$ circle during the period under study. The negative change in area under other fallows was recorded in Latur $(0.17 \%)$, Kasarkheda $(0.69 \%)$, Murud $(0.61 \%)$, Gategon $(0.55 \%)$, Tandulja $(1.31 \%)$, Nilanga (0.68\%), Shirur Anatpal (0.57\%), Hismabad (0.24\%), Ambulga (1.23\%), Kasarshirsi (0.74\%), Kasarbalkunda (0.93\%), Madansuri (0.64\%) and Aurad shajani $(0.31 \%)$ circles.

\subsubsection{Transformations in Net Sown Area:}

Due to utilization of fallow land the net sown area has been increased in study area. Only positive change was recorded in the area of net sown during the period under study. The positive change in net sown area was recorded by 5.2 Overall Volume of Change in General Land from 19931996 to 2010-13:

After the consideration of all the land use categories, it is necessary to measure the overall volume of change of nine general land use from 1993-1996 to 2010-13. In overall volume of change includes the land actually involved in the transform from one category to the other category. If the index Table 1

Land Utilization of Different Circles of St

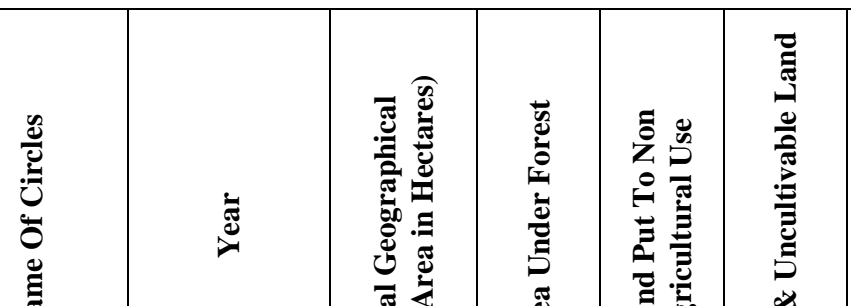


International Journal of Computer Applications Technology and Research

Volume 6-Issue 8, 369-373, 2017, ISSN:-2319-8656

dynamic conditions exist there. Table no. 2 indicates that an index of different circles of the study region. The index of volume of change was more than $19 \%$ were observed for Kasar Balkunda (19.26\%) means the dynamic conditions of land use 
International Journal of Computer Applications Technology and Research

Volume 6-Issue 8, 369-373, 2017, ISSN:-2319-8656

\begin{tabular}{|c|c|c|c|c|c|c|c|c|c|c|c|}
\hline \multirow{5}{*}{ Kasar Shirsi } & 1993-96 & 14907 & 65 & 622 & 367 & 321 & 325 & 122 & 211 & 159 & 12715 \\
\hline & $\%$ & 100 & 0.44 & 4.17 & 2.46 & 2.15 & 2.18 & 0.82 & 1.42 & 1.07 & 85.30 \\
\hline & $2010-13$ & 14907 & 151 & 355 & 167 & 94 & 184 & 98 & 77 & 49 & 13732 \\
\hline & $\%$ & 100 & 1.01 & 2.38 & 1.12 & 0.63 & 1.23 & 0.66 & 0.52 & 0.33 & 92.18 \\
\hline & Vol. of ch. & 00 & 0.57 & -1.29 & -1.34 & -1.52 & -0.95 & -0.16 & -0.9 & -0.74 & 6.88 \\
\hline \multirow{5}{*}{ Kasar Balkunda } & 1993-96 & 21166 & 201 & 2078 & 1227 & 998 & 537 & 432 & 315 & 400 & $\begin{array}{l}4978 \\
\end{array}$ \\
\hline & $\%$ & 100 & 0.95 & 9.82 & 5.80 & 4.72 & 2.53 & 2.04 & 1.49 & 1.89 & 70.76 \\
\hline & $2010-13$ & 21166 & 230 & 727 & 304 & 300 & 128 & 135 & 114 & 204 & 19024 \\
\hline & $\%$ & 100 & 1.09 & 3.43 & 1.44 & 1.42 & 0.60 & 0.64 & 0.54 & 0.96 & 89.88 \\
\hline & Vol. of ch. & 00 & 0.14 & -6.39 & -4.36 & -3.3 & -1.93 & -1.4 & -0.95 & -0.93 & 19.12 \\
\hline \multirow{5}{*}{ Madansuri } & $1993-96$ & 15170 & 20 & 877 & 398 & 295 & 435 & 221 & 186 & 190 & 12548 \\
\hline & $\%$ & 100 & 0.13 & 5.78 & 2.62 & 1.94 & 2.87 & 1.46 & 1.23 & 1.25 & 82.72 \\
\hline & $2010-13$ & 15170 & 35 & 335 & 184 & 168 & 212 & 186 & 84 & 93 & 13873 \\
\hline & $\%$ & 100 & 0.23 & 2.21 & 1.21 & 1.11 & 1.40 & 1.23 & 0.55 & 0.61 & 91.45 \\
\hline & Vol. of ch. & 00 & 0.10 & -3.57 & -1.41 & -0.83 & -1.47 & -0.23 & -0.68 & -0.64 & 8.13 \\
\hline \multirow{5}{*}{ Auradsha } & $1993-96$ & 16214 & 271 & 418 & 242 & 258 & 124 & 128 & 230 & 198 & 14345 \\
\hline & $\%$ & 100 & 1.67 & 2.58 & 1.49 & 1.59 & 0.76 & 0.79 & 1.42 & 1.22 & 88.47 \\
\hline & $2010-13$ & 16214 & 89 & 132 & 144 & 85 & 68 & 87 & 198 & 148 & 15263 \\
\hline & $\%$ & 100 & 0.55 & 0.81 & 0.89 & 0.52 & 0.42 & 0.54 & 1.22 & 0.19 & 93.97 \\
\hline & Vol. of ch. & 00 & -1.72 & -1.77 & -0.6 & -1.07 & -0.34 & -025 & -0.2 & -0.31 & 5.5 \\
\hline \multirow{5}{*}{$\begin{array}{l}\text { Total Latur \& } \\
\text { Nilanga }\end{array}$} & 1993-96 & 257735 & 921 & $\begin{array}{c}1275 \\
1\end{array}$ & 5960 & 5778 & 4974 & 3764 & 3092 & 2818 & 217800 \\
\hline & $\%$ & 100 & 0.36 & 4.95 & 2.31 & 2.24 & 1.93 & 1.46 & 1.20 & 1.09 & 84.51 \\
\hline & $2010-13$ & 257735 & 1702 & 76.09 & 2879 & 2796 & 2082 & 1552 & 1245 & 1069 & 237409 \\
\hline & $\%$ & 100 & 0.66 & 2.95 & 1.12 & 1.08 & 0.81 & 0.60 & 0.48 & 0.41 & 92.11 \\
\hline & Vol. of ch. & 00 & 0.3 & -2 & -1.19 & -1.16 & -1.12 & -0.86 & -0.72 & -0.68 & 7.2 \\
\hline
\end{tabular}

is observed in this circle. A semi-dynamic land use condition has been recorded in Tandulja (9.45\%), Ambulga (9.59), Murud (7.09\%), Nilanga (7.44\%), Shirur Anatpal (5.44\%), Hismabad (6.73), Kasarshirsi (6.88) and Aurad Shajani (5.5\%) and madansuri (8.83) circles. The static conditions din land has been observed in Latur (1.79\%), Kasarkheda (4.72\%) and Gategaon (4.90\%) circles. (Table No. 2 and Map No. 3)

Categorywise more change has observed in land put to non agricultural use and net sown area. Negative change has observed in land put to non agricultural use, barren lands, permanent pastures and other grazing land, area under miscellaneous tree crops etc., cultural waste land, current fallows and other fallow land positive change has observed Net sown and area under forest. It is good sign for study area development. (Figure 1)

\section{ACKNOWLEDGMENTS}

I thanks to my guide principal Dr. B. G. Sonwane for valuable guidance for this research work. Also I would like to express thank to cartographer Dr. Parmeshwar Poul.
(1993-1996 to 2010-13)

\begin{tabular}{|c|c|c|}
\hline $\begin{array}{c}\text { Sr. } \\
\text { No. }\end{array}$ & Name of The Circle & $\begin{array}{c}\text { Volume of Change } \\
\text { Index in \% }\end{array}$ \\
\hline 1 & Latur & 1.79 \\
\hline 2 & Kasarkheda & 4.72 \\
\hline 3 & Murud & 7.09 \\
\hline 4 & Gategoan & 4.90 \\
\hline 5 & Tandulja & 9.45 \\
\hline 6 & Nilanga & 7.44 \\
\hline 7 & Shirur Anantpal & 5.44 \\
\hline 8 & Hisamabad & 6.73 \\
\hline 9 & Ambulga & 9.59 \\
\hline 10 & Kasarshirsi & 6.88 \\
\hline 11 & Kasar Balkunda & 19.26 \\
\hline 12 & Madansuri & 8.83 \\
\hline 13 & Aurad shajani & 5.5 \\
\hline 14 & Total Latur \& Nilanga & 7.2 \\
\hline
\end{tabular}

Source: Computed by Author

Table 2

Volume of change in General Land Use 

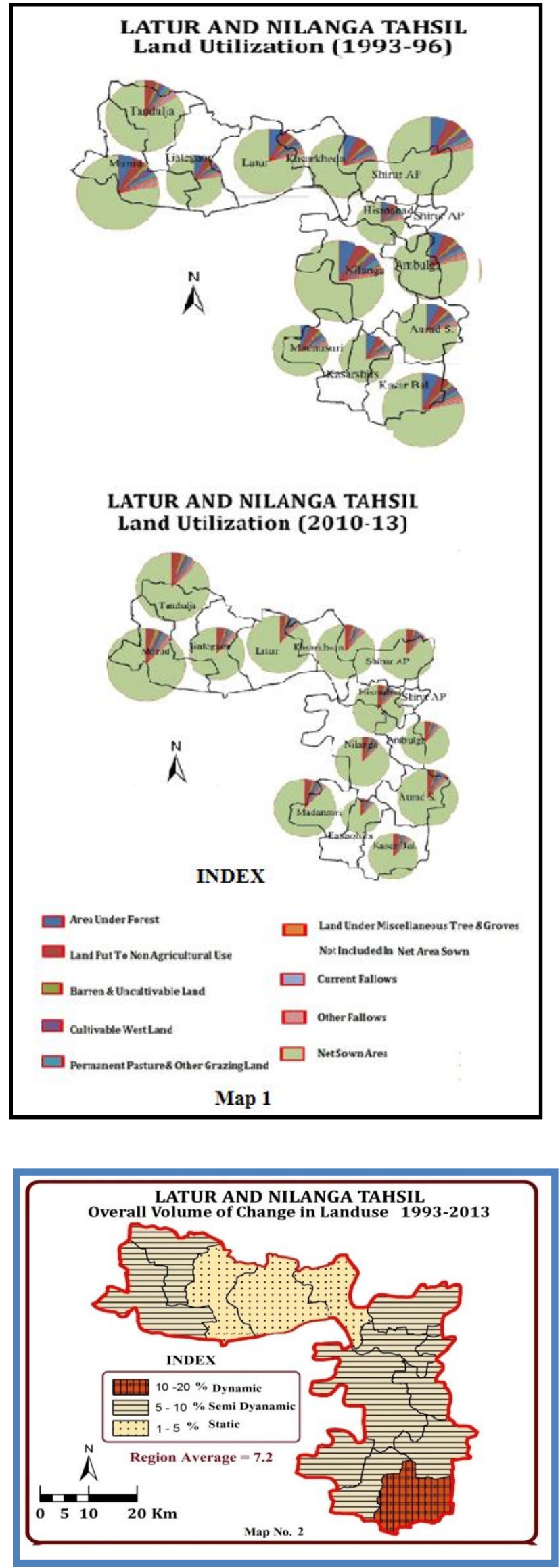

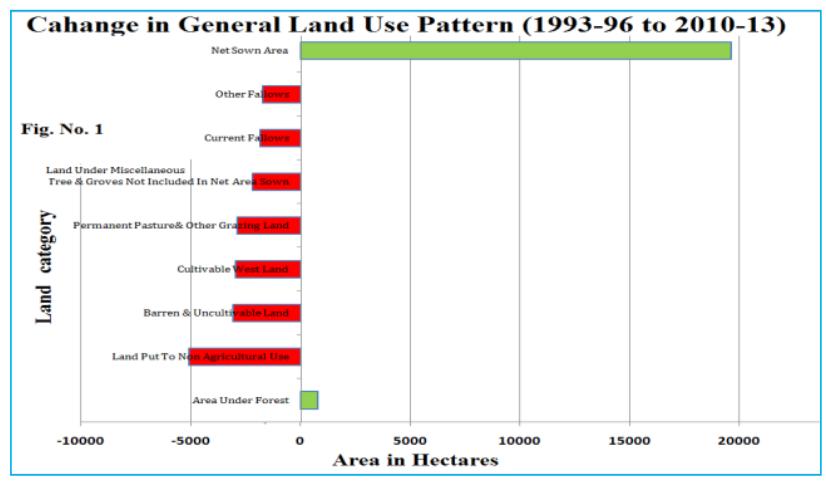

\section{REFERENCES:}

[1] Das, M. M. (1981): "Land Use Pattern in Assam", Geographical Review of India, Vol.43, No.3, pub by Calcutta, Geographical society of India, 1981, 243-244.

[2] Jasbir Sing \& S.S. Dhillon (1984): "Agricultural Geography", Tata Mc Graw Hill Publishing comp. 1td; New Delhi 1984, 112-113.

[3] Jainendra Kumar (1935) : Land use. Analysis Intra India publication New Delhi. 65

[4] Majid Husain (1979): “Agricultural Geography” IntraIndia publication, Delhi 1979,114 - 155

[5] Socio - Economic review of Latur District (1993-2013): Govt. of Maharashtra.

[6] Statistical review reports (1993-2013): Panchyat Samiti of Latur and Nilanga

[7] Socio-Economic reviews \& district stastical abstract, Latur district, Latur (1993-96 to 2010-13): 